\title{
PARKFIELD EARTHQUAKES OF JUNE 27-29, 1966, MONTEREY AND SAN LUIS OBISPO COUNTIES, CALIFORNIA- PRELIMINARY REPORT
}

\author{
ABSTRACT
}

Two earthquakes, $M=5.3$ and 5.5 , shook the Parkfield area in southern Monterey County, California, at 0409:56.5 and 0426:13.8 GMT, 28 June 1966. They were preceded by foreshocks on the same day cit 0100 and 0115 . A third shock, $M=5.0$, occurred in the same area at 1953:26.2 on 29 June. The earthquakes were followed by a heavy sequence of aftershocks with epicenters along the San Andreas fault zone extending for about 15 miles southward beyond Cholame in San Luis Obispo County. A P-wave first-motion fault plane solution shows strike of vertical fault plane is $N 33^{\circ} \mathrm{W}$, coinciding with a surface zone of en echelon fault fractures in the pattern characteristic of rightlateral, strike-slip movement. The motion appears to have an upward component on the west side, at about $20^{\circ}$ from pure strike slip. Extensive instrumentation within a few miles of the epicentral district gave unusually complete records from foreshock to aftershock sequence. A strong-motion instrument in the fault zone near Cholame recorded the unusually high horizontal acceleration of $0.5 \mathrm{~g}$.

The epicentral region of the earthquakes is on a known active segment of the San Andreas fault. Earthquakes in 1901, 1922, and 1934 in this region were also accompanied by surface faulting. On the published State geologic map, scale 1:250,000, the San Andreas fault zone shows a braided pattern of several branching en echelon major faults. Topographic forms, typical of the features of rift valleys, testify to the recency of fault movements. Small right-lateral surficial displacements had been recognized prior to the late June earthquakes in at least three places on the Parkfield-Cholame trace of the fault. Similar creep, or slippage, has continued since the earthquakes. Extensive nets of survey markers installed by 30 June across the active fault trace had recorded slippage as great as 0.1 inch per day by 12 July. The fault trace associated with the earthquakes is principally in alluvium of unknown depth in Cholame Valley, apparently a faulted graben within the San Andreas fault zone. Under a blanket of Tertiary and Quaternary sedimentary rocks in this part of the southern Coast Ranges, the great fault separates Jurassic-Cretaceous granitic and metamorphic rocks in the western block from Late Jurassic eugeosynclinal sedimentary and volcanic rocks of the Franciscan Formation in the eastern block.

In spite of the large horizontal acceleration recorded near the fault, very little building damage occurred in this sparsely populated region. Small concrete and steel bridges in, and adjacent to the fault trace, did not have their structural strength impaired.

\section{Geologic Features-Gordon B. Oakeshott ${ }^{1}$}

The epicentral region of the earthquakes of late June 1966 is on a known active

\footnotetext{
${ }^{1}$ California Division of Mines and Geology, San Francisco.
} 


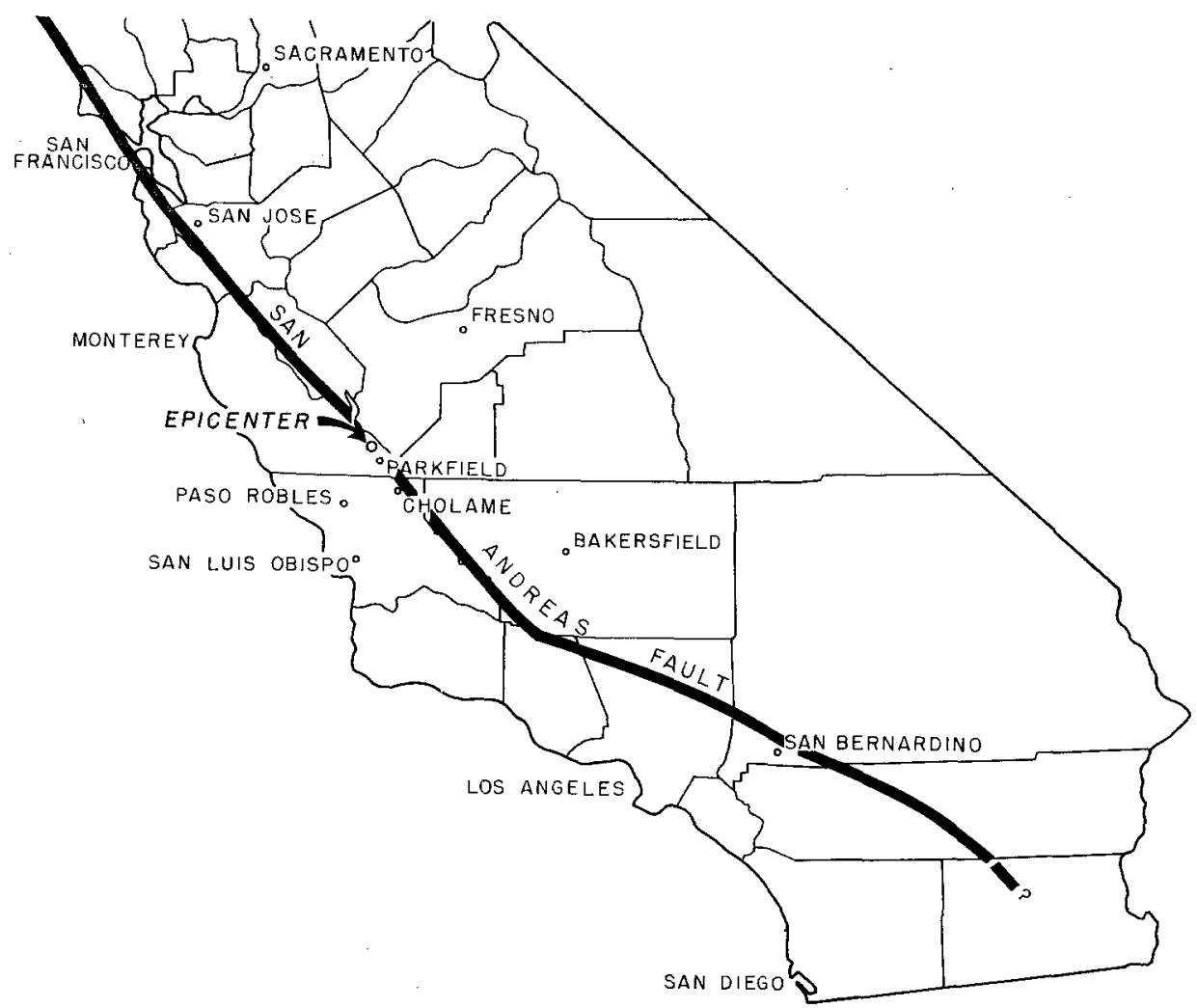

Fig. 1. Index map showing San Andreas fault south of San Francisco and approximate location of epicentral area of Parkfield-Cholame earthquakes of late June 1966

segment of the San Andreas fault in the southern Coast Ranges (Fig. 1). East of the fault zone is the southern end of the Diablo Range; on the west the Cholame Hills merge southward into the Temblor Range. In terms of geologic history, the most important feature of the San Andreas fault is that it here marks the contact between Cretaceous-Jurassic granitic rocks and older marble and amphibolite of the Sur Series (Hay, 1963) in the western block with the eastern block composed of Late Jurassic eugeosynclinal sedimentary and volcanic rocks of the Franciscan Formation and intruding serpentine (Fig. 2). Rocks of these two "basement" units are sliced together within the great fault zone. Thick Early to Late Cretaceous miogeosynclinal sandstones and shales overlie Franciscan units in the Diablo Range. Marine Eocene and Miocene rock formations occur in the Diablo-Temblor Ranges block.

FIG. 2. Geologic and topographic map of the Cholame-Parkfield area, scale approximately 1:250,000; San Luis Obispo sheet of State Geologic Map, California Division of Mines and Geology. Cross hatching shows trace of surface faulting as mapped in reconnaissance by Cluff, Oakeshott, Slemmons, and Steinbrugge, 8 and 9 July 1966; direction of lines suggests orientation of en echelon fault fractures. Note discontinuity of fault trace at a point in southern Cholame Valley. Geologic symbols pertinent to the fault zone: gr-granite and Sur Series, KJf-Franciscan Formation, ub-serpentine, $K 1$ and $K u$-Lower and Upper Cretaceous formations, E-Eocene formations, M-Miocene formations, Pml-middle and lower Pliocene formations, QP-Plio-Pleistocene non-marine formations, QT-terrace deposits, and Qal-alluvium of Cholame Valley. 


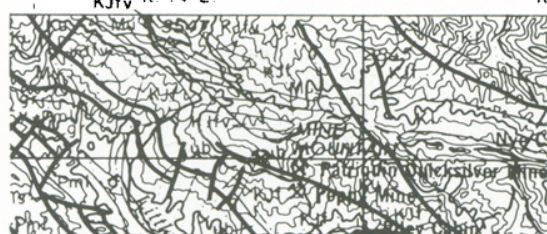

(1)

(n) 135 . Mo 30.

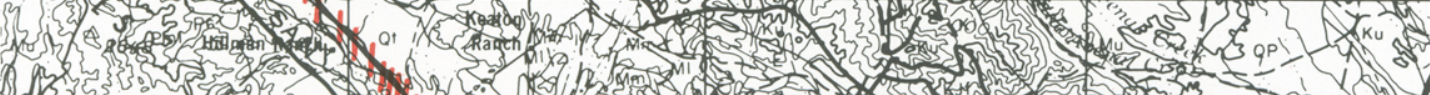

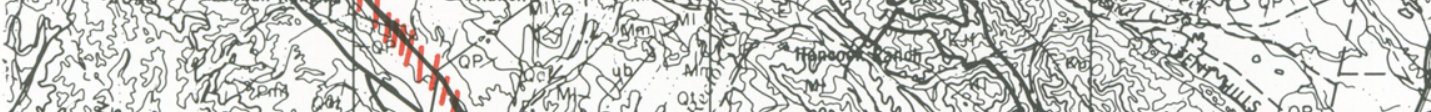

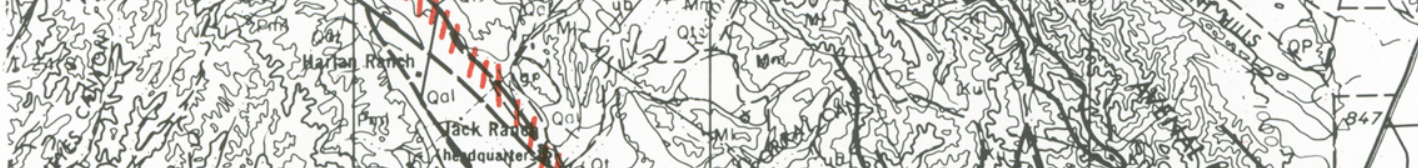

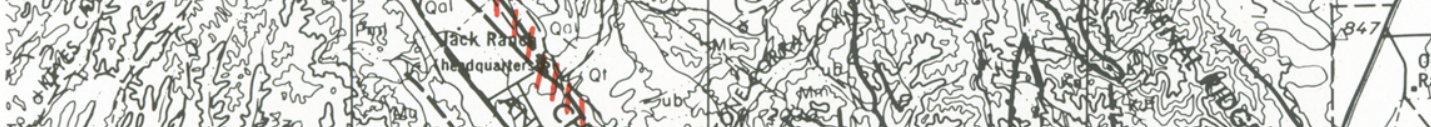

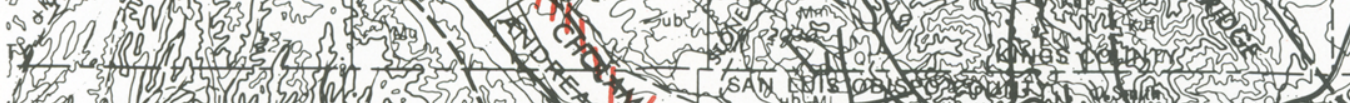

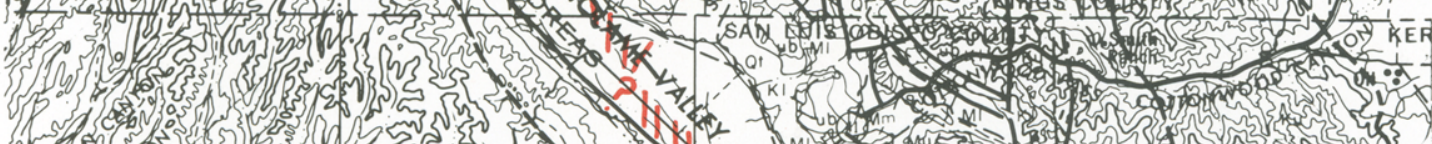

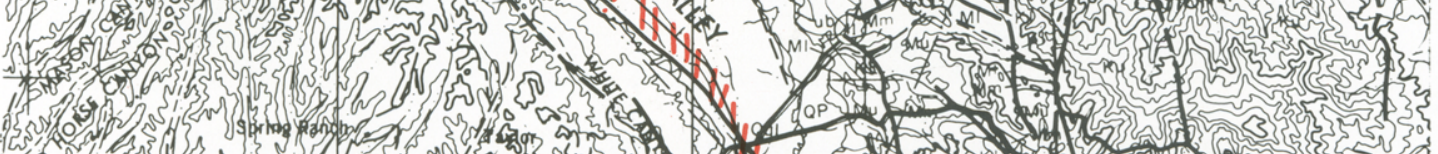
20 $x^{2}$ is

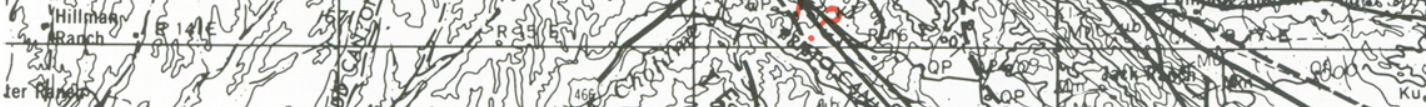
*

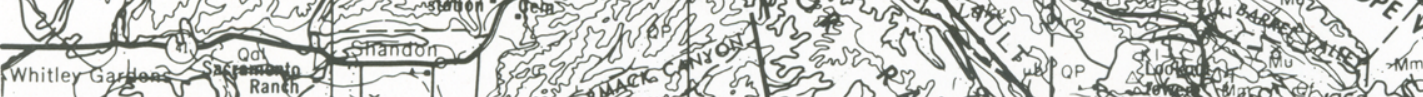

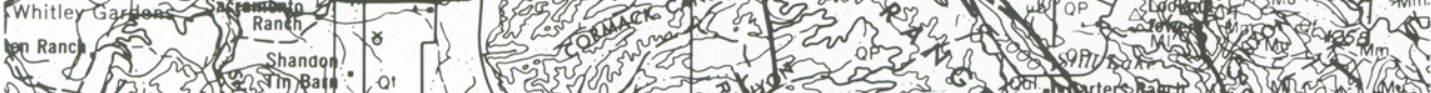

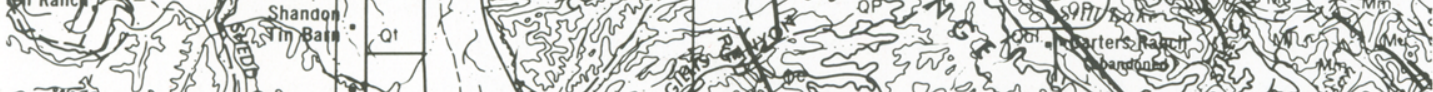

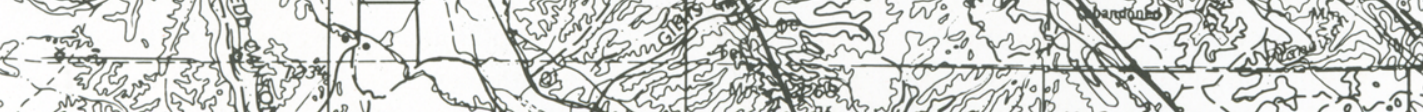
, 3,

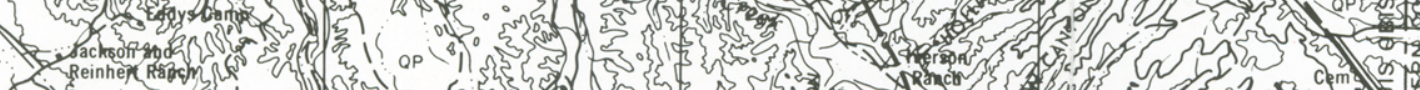
.

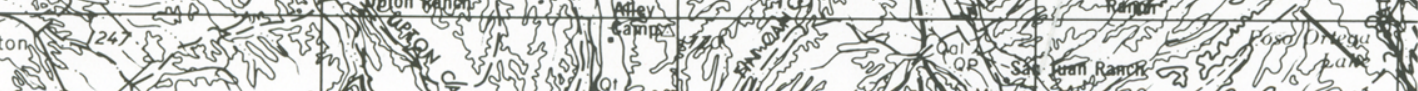
Is 


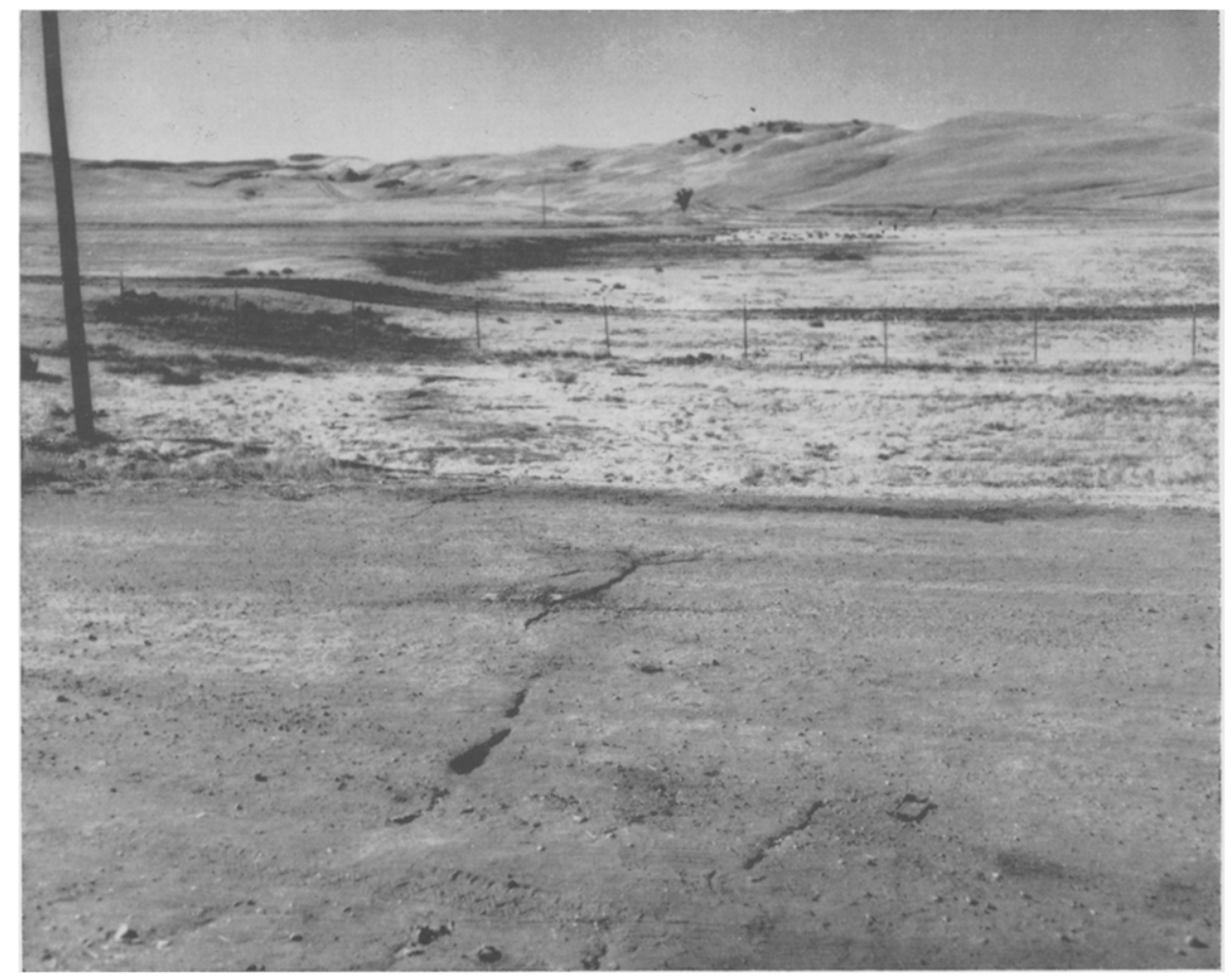

Fig.3. En echelon fractures in fault trace accompanying earthquakes of late June 1966. Looking southward from Highway 46 near Cholame. Note especially the right-lateral fracture pattern. Current faulting follows the trace of the latest pre-historic scarps. Photo by Lloyd $S$. Cluff; Woodward, Clyde, Sherard, and Assoc., 8 July 1966.

Shallow-water marine sedimentary formations of late Miocene to middle Pliocene age crop out widely on both sides of the fault zone and are sliced into it. Such formations are commonly called Pancho Rico (in part late Miocene) and JacalitosEtchegoin west of the fault zone, and Jacalitos, Etchegoin, and San Joaquin (late Pliocene) east of the San Andreas fault. Pliocene marine formations grade upward into, or are locally unconformably overlain, by very widespread partiy consolidated nonmarine conglomerate, sandstone, and mudstone of late Pliocene to early Pleistocene age. These sedimentary formations of river flood-plain, channel, and intermittent-lake origin are called Paso Robles Formation west of the fault zone and Tulare and McKittrick Formations on the east. The Paso Robles Formation, in some places over a thousand feet thick forms a horizontal to gently-dipping blanket 25 miles wide west of the fault. In the San Andreas fault zone these beds and their correlatives are steeply folded, faulted, and sometimes overturned. Fragments of flat-lying stream-terrace gravels of late Quaternary age are widely distributed. Cholame Valley is buried in Recent alluvium and lake beds(?) to an unknown depth. The valley appears to be a graben in this segment of the fault zone.

The San Andreas fault, as mapped in the Cholame-Parkfield area, shows a braided pattern of several branching and en echelon major faults. Topographic forms, such 


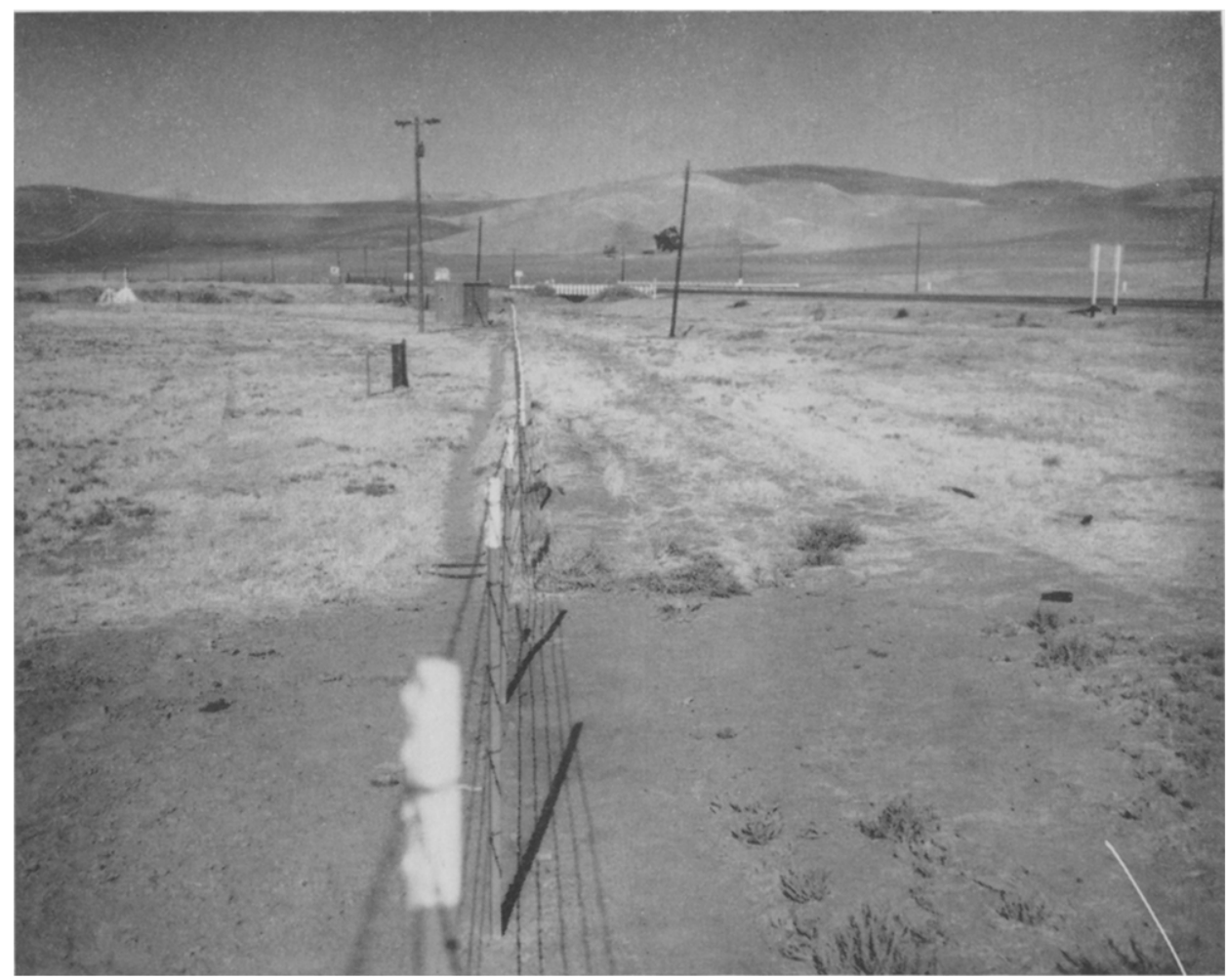

FIG. 4. Fence warped about 4 inches, in right-lateral sense, near center of photo; fault trace from $\mathrm{R}$ to $\mathrm{L}(\mathrm{N}$ to $\mathrm{S}$ ) across center of picture. Small building houses strong-motion equipment of station 2 of C\&GS (Fig. 7). Photo by Lloyd S. Cluff; Woodward, Clyde, Sherard, and Assoc., 8 July 1966.

as trenches, pressure ridges, strike valleys, and all the minor features of rift valleys, testify to the recency of fault movements.

Surface fault movements at the time of the June 1966 earthquakes follow precisely the most recent trace of older faulting (Fig. 3). Surface fault fractures, as traced for some fifteen miles a few days after the earthquakes, consist of a series of large numbers of minor fractures arranged in an en echelon, chevron pattern; that is, the fault trace itself trends approximately north 30 degrees west, while the irregular fractures trend in most cases from due north, or slightly east of due north, to about north $10^{\circ}$ or $15^{\circ}$ west. This is the type of fracture pattern that is developed in the land surface due to shearing as a result of movement of the east block of the earth's surface toward the south relative to the block west of the fault. Such movement is characteristic of the San Andreas fault. Many of the fractures observed were open cracks 2 to 4 inches wide developed by local tension, but some fractures were closed and the soil was forced up into pressure ridges or "mole tracks" a few inches high as a result of local compression. The amount of surface movement as measured at many points in the field was found to be on the order of 2 to 4 inches horizontal in the right-lateral sense (Fig. 4). 


\section{ACKNOWLEDGMENTS}

Discussions in the field with Lloyd S. Cluff, D. B. Slemmons, and Karl V. Steinbrugge are greatly appreciated. In addition to the individual authors of the sections which follow, useful information is gratefully acknowledged from M. G. Bonilla, R. O. Castle, J. P. Eaton, R. Kachadoorian, J. Schlocker, and R. F. Yerkes, all of the U. S. Geological Survey.

\section{REFERENCES}

Byerly, Perry, and Wilson, James T. (1935). The central California earthquakes of May 16, 1933 and June 7, 1934, Bull Seism. Soc. Amer., 25, no. 3, p. 223-246.

California Div. of Mines and Geology (1958), Geologie map of California, San Luis Obispo sheet; compiled by Charles W. Jennings.

Hay, Edward A. (1963). Age and relationships of the Gold Hill pluton, Cholame Valley, California, Guidebook to the geology of Salinas Valley and the San Andreas fault, Amer. Assoe. Petroleum Geologists, Pacific Sect.

Pre-Earthouake and Post-Earthquake Surfictal Displacements-Clarence R. Allen ${ }^{2}$ and Stewart W. Smith ${ }^{2}$ (12 July 1966)

Surficial displacements had been taking place along the Quaternary trace of the San Andreas fault south of Parkfield for several years prior to the earthquake of 27 June 1966. Mr. Harlan Durham of Parkfield had earlier pointed out that the asphalt of the Parkfield-Cholame road had to be repaired several times during the preceding two or three years at the point where the fault trace crossed, about 4 $\mathrm{km}$ southeast of Parkfield; the southwest side had evidently gone up slightly, and a zone of en-echelon cracks cross the road suggested small right-lateral movements along a nearby branch. The same area was visited on 16 June 1966 by a field-trip group of the Second U. S.-Japan Conference on Research Related to Earthquake Prediction, and very fresh-appearing en-echelon cracks-probably less than one month old-were noted at that time along the fault trace on the Taylor Ranch, $1.7 \mathrm{~km}$ southeast of Parkfield. These cracks were widened, extended, and multiplied during the earthquake of 27 June, 11 days later. Local residents stated that both of these localities had also been the sites of much larger en-echelon cracks at the time of the 1934 Parkfield earthquake $(M=6)$. Because of the evidence of active displacements, micro-earthquake studies were carried out in this area by Dr. James Brune on 18-19 June 1966, and a 24-hour record shows no identifiable micro-earthquakes ( $\mathrm{M} \geqq 0$ ) within $24 \mathrm{~km}$, although similar observations made here one day after the earthquake ( 9 days later) show more than 2400 such events per day.

Initial ground displacement along the fault during the earthquake is unknown, but at 7:00 AM (PDT) on 28 June, 10 hours following the main shock, the white line on the highway $1.5 \mathrm{~km}$ east of Cholame had been offset $4.5 \mathrm{~cm}$ in a right-lateral sense along the Quaternary fault trace. By that evening the displacement had increased to $6.4 \mathrm{~cm}$ and was $7.5 \mathrm{~cm}$ by the following noon, when more sophisticated geodetic observations in the area commenced. Unlike the fault break farther north, the relatively new pavement here apparently was not cracked prior to the June 27 th event, although very old fence lines nearby had been offset more than $30 \mathrm{~cm}$

${ }_{2}^{2}$ California Institute of Technology, Pasadena. 
along the fault sometime in the years prior to this shock. Repeated theodolite observations showed increasing fault displacements at several localities during the days following the earthquake; 5 measurements by Mr. Max Wyss at the Taylor Ranch locality near Parkfield showed a continuing horizontal displacement of about $7 \mathrm{~mm}$ /day between 29 June and 8 July, although other localities showed intermittent displacements. Observations with a tiltmeter, quartz extensometer, and long-period pendulums installed in and across the fault zone at Carr Ranch, $10 \mathrm{~km}$ southeast of Parkfield, tentatively indicate that continuing fault displacements here are associated with individual aftershocks in addition to uniform creep.

\section{U. S. Geologrcal Sunvey Investigations-L. C. Pakiser ${ }^{3}$ (13 July 1966)}

In October 1965 a 3-component short-period (Benioff) seismograph station was established at Gold Hill on Jack's (Cholame) Ranch between Cholame and Parkfield for the purpose of recording seismic waves generated by the Long Shot nuclear explosion at Amchitka. This station has operated continuously since installation, and recorded the events of 27 June and the following days in the epicentral region. On 30 June, and the days immediately following, an additional eight portable seismograph stations were installed in a rectangle extending about 12 miles along the San Andreas fault and about 5 miles on both sides of the fault. The net of portable stations is centered near Cholame.

On 30 June and the following days, seven quadrilaterals of survey markers were installed. The first of these nets includes a straight "picket fence" of markers across the fault, as well as two nested quadrilaterals with diagonals of 200 feet and 20 feet. The largest rate of slippage observed of these quadrilaterals is about 0.1 inch per day.

Field mapping over a fault length of 17 miles of continuous ground breakage is being continued. Pre- and post-earthquake black-and-white photography and infrared imagery are being used along with conventional methods of geologic mapping. The Engineering Geology Branch is studying the relations of structural failure to foundation conditions. Small but extensive landslides followed the initial shock and sliding occurred on surface slopes as small as 5 or 10 degrees.

\section{Preliminary Seismic Data, June-July 1966-T. V. MeEvilly ${ }^{4}$ (15 July 1966)}

The sequence began with two foreshocks at 0100 GMT and 0115 GMT, June 28,1966 . These were of magnitudes about 3 and 2, respectively. The University of California telemeter station at Priest (PRI), $26 \mathrm{~km}$ from the main shock, and the USGS Gold Hill station at $18 \mathrm{~km}$, should be sensitive to earthquakes in the region of magnitudes as low as 0.5 to 1.0. At this threshhold, no other foreshocks are apparent, although there is the normal incidence of small earthquakes in the general area, mainly north and northwest some 50 or more kilometers.

The two largest earthquakes of the sequence occurred at 0409:56.5 ( $M=5.3 \mathrm{BRK}$,

${ }^{3}$ U. S. Geological Survey, Menlo Park.

${ }^{4}$ University of California, Berkeley. 


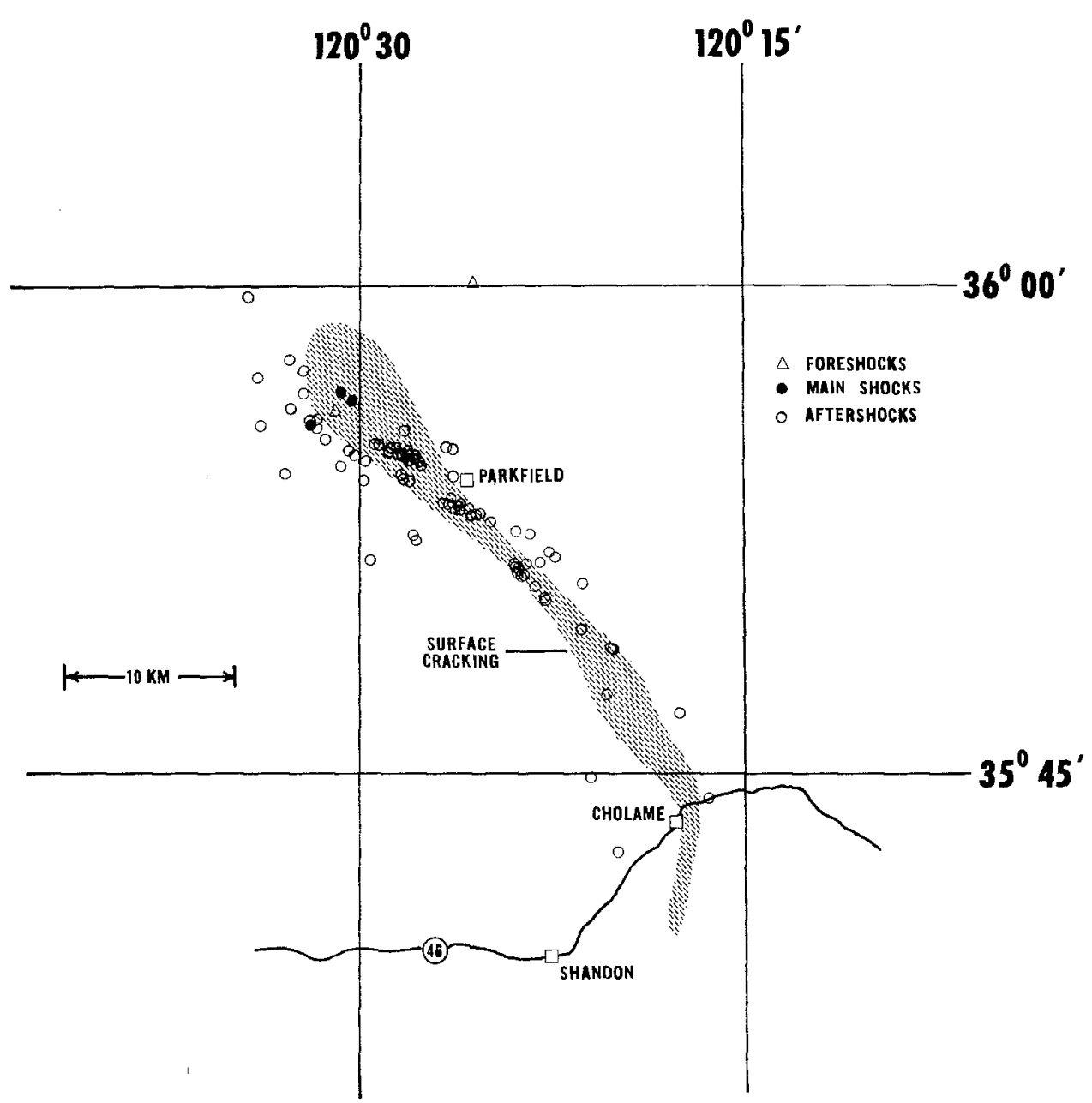

Frg. 5. Preliminary epicenter locations for 85 earthquakes in the sequence. Shaded area indicates general outline of cracking from available reports.

4.8 PAS) and 0426:13.8 ( $M=5.5 \mathrm{BRK}, 5.6 \mathrm{PAS})$, with a smaller event ( $M=2.5 \pm$ ) between them at 0418. The third major shock in the sequence occurred on June 29 at 1953:26.2 ( $M=5.0 \mathrm{BRK}, 4.8 \mathrm{PAS})$. The three largest events are separated by at most 3-4 $\mathrm{km}$ distance.

With the magnitude 5.5 earthquake began a very heavy sequence of aftershocks. In the first two and one-half hours, PRI recorded over 100 aftershocks (probably $M>0.5 \pm$ ). The UC mobile station was recording south of Parkfield by 1100 hours. At this time aftershocks were being recorded at about 1 per minute at relatively low magnification $(\sim 4 K)$. From the larger events $(M>2)$, it seems that about 50 per cent of the aftershocks occurred in the first 24 hours. A preliminary " $b$ " value for the $\log N$ vs magnitude curve for the sequence is -.41 . This is similar to the 1963 Watsonville sequence but much lower than values for the 1964 Corralitos and 1965 Antioch, California sequences. All have main shocks in the magnitude 5-5.5 range. The " $b$ " values below 0.5 seem to be characteristic of sequences distributed over an area a few tens of kilometers in length and main shock 


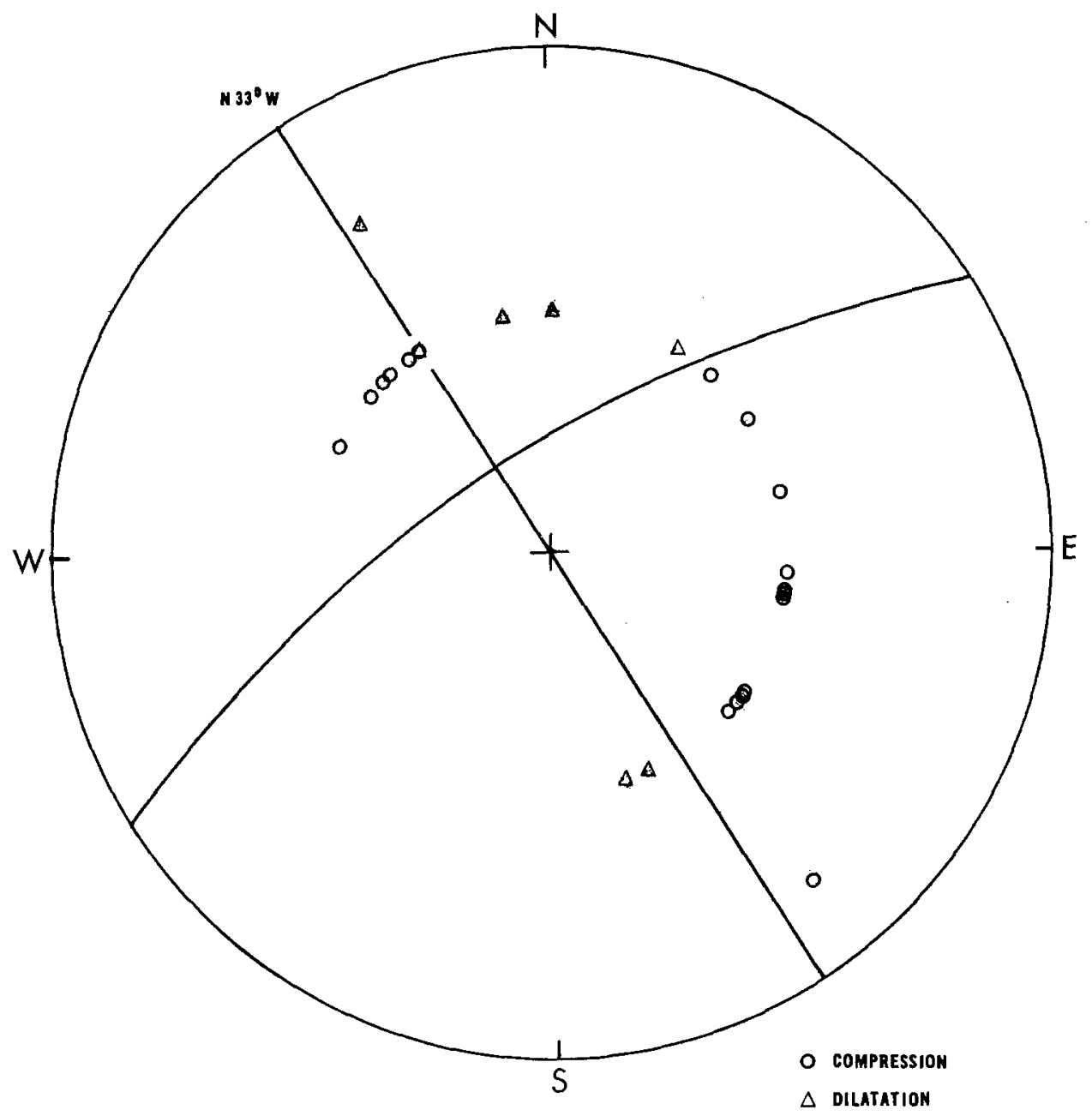

FIG. 6. $P$-wave fault plane solution for large shocks of 28 June.

magnitudes near 5.5, while values of 0.6 to 0.9 appear to be associated with "point source" type sequences, associated with main shock magnitudes near 5.0, where all the aftershocks occur within a zone a few kilometers long.

Intensity data from surveys by $U C$ personnel and felt-report cards distributed by USCGS, San Francisco, indicate a maximum MM intensity, ignoring the cracking, of VII to VIII along the zone of reported cracking about $35 \mathrm{~km}$ in extent, from $10 \mathrm{~km} \mathrm{NW}$ of Parkfield to some $5 \mathrm{~km} \mathrm{~S}$ of Cholame. The felt area ranges roughly from Santa Cruz $(190 \mathrm{~km} \mathrm{NW})$ to Oxnard (225 km SE) and northeastward about $150 \mathrm{~km}$ into the Sierra Nevada foothills.

Preliminary epicenters for 85 earthquakes of $M>2 \pm$ occurring through July 7 are shown in figure 5. To maintain accurate relative positions of the points, only three stations were used, Paraiso, Priest, and either the UC mobile station or Gold Hill (3 km apart), with focal depth constrained. Accurate depth information, for the later events of the sequence, will come from some 20 temporary stations set 


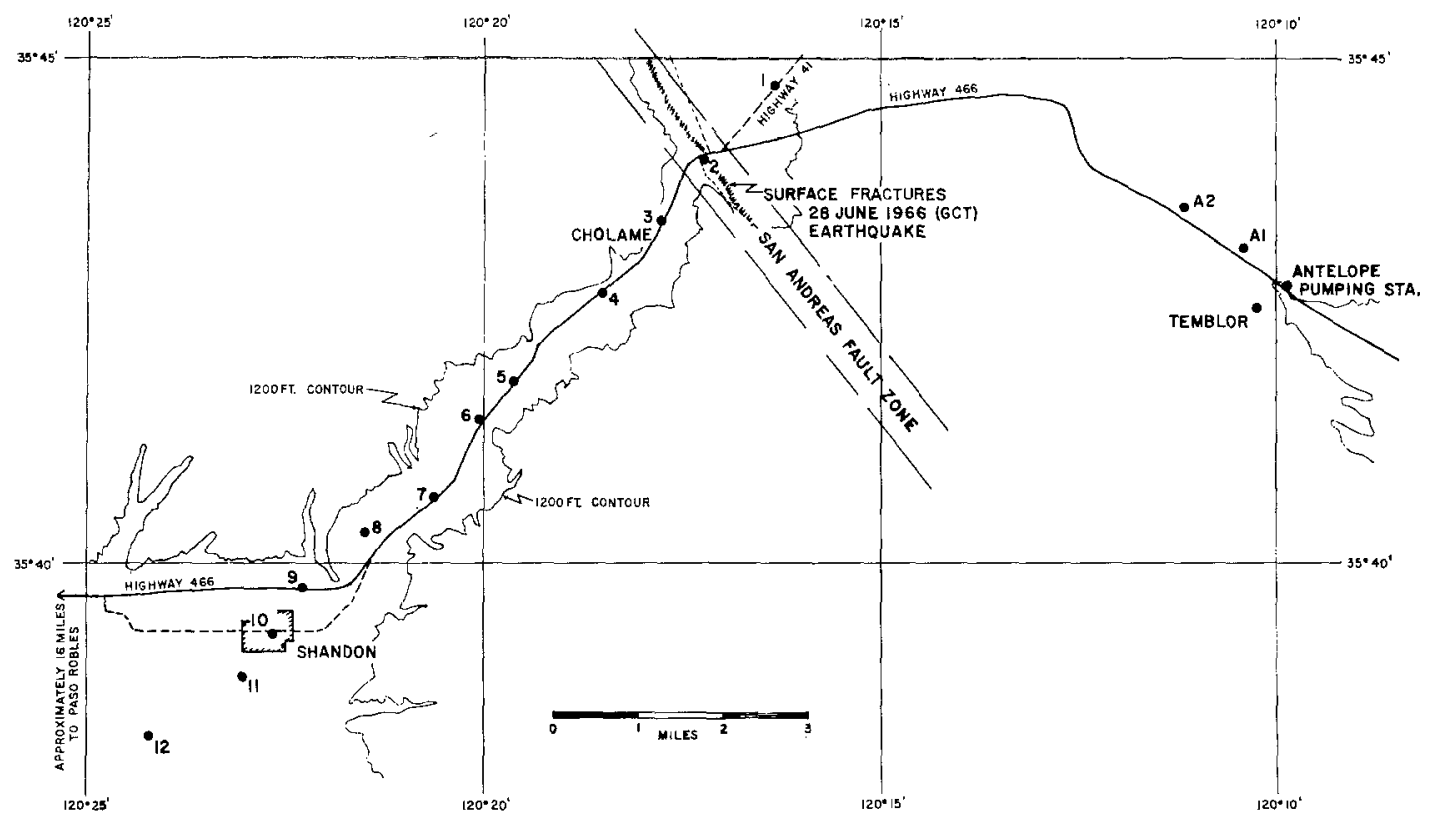

FIG. 7. Cholame-Shandon array of strong-motion stations of C\&GS.

up in the area. Preliminary depths for a few aftershocks using both the UC stations and USGS station in the epicentral region appear to be around 10-12 km. Using a $10 \mathrm{~km}$ depth constraint, the epicenters shown in the figure were obtained. A rough indication of the extent of surface breakage observed and reported by residents in the area is also shown.

A $P$-wave first-motion fault plane solution from available data is shown in figure 6. The two large shocks of June 28 have identical solutions. The velocity model used in this projection is the same as applied in previous sequence studies in central California, assuming a linear velocity increase in the crust. The strike of the vertical fault plane (ambiguity can be removed with some confidence in this case) is $\mathrm{N} 33^{\circ} \mathrm{W}$, coinciding with the trend of the crack zones in the field. The motion appears, in the fault plane solution, to have an upward component on the west side, at about $20^{\circ}$ from pure strike-slip motion. There are (so far, 15 July) no inconsistent points in the solution.

The UC summary file of California earthquakes lists three previous large earthquakes in the Cholame Valley near Parkfield. On March 3, 1901, March 10, 1922, and June 8, 1934 earthquakes of magnitudes apparently near 6 occurred in the area. Cracks in the ground hundreds of feet long were reported in 1901 and 1922. Aftershocks are reported in both instances, the largest following the 1922 earthquake reported on March 16 and August 18. In 1934 earthquakes of magnitudes near 5 on June 6 , and June 8,17 minutes before the main shock (interestingly, the 1966 large earthquakes are separated by 16 minutes). Several magnitude 3 to 4.5 aftershocks followed these earthquakes. Magnitude 5 shocks occurred in the same area December 24, 1934, December 28, 1939, and November 16, 1956. The largest events in the 10 years before the current sequence were on October 10, 1958 ( $M$ $=4.5)$ and July $31,1961(M=4.7)$. 
Data for this initial study have been generously supplied, on a rush basis, by Dr. Jerry Eaton of USGS and Dr. Charles Richter of the California Institute of Technology. William Bakun and Kenneth Casaday of the UC Seismographic Stations have undertaken the detailed data processing of the sequence.

\section{Strong-Motion Records-William K. Cloud ${ }^{5}$ (12 July 1966)}

Excellent records were obtained from 5 strong-motion seismographs and 16 seismoscopes installed by the ESSA, C\&GS, adjacent to and within 10 miles of surface ruptures of the San Andreas fault (Fig. 7). An unusual feature of the earthquake, judged from preliminary inspection of the records and from field investigations, was high acceleration of short duration (maximum 0.5g at Station 2 (Fig. 7)) adjacent to surface ruptures, but remarkably little damage to man-made structures in the epicentral area.

Strong-motion instrumentation of the area was covered by a cooperative agreement with the California Department of Water Resources.

\section{Structural Damage-Karl V. Steinbrugge ${ }^{6}$ (15 July 1966)}

Very little building damage occurred, in part due to the wood frame construction generally found in the heaviest shaken areas. Items often fell from shelves, but some locations within a mile of the fault trace had very little damage of this type. For one example, in a restaurant less than a mile from the fault trace, only a few glass items fell from shelves despite many similar objects being located near the edge of shelving.

Several headstones overturned in the old and new Parkfield cemeteries.

A small concrete bridge adjacent to the 4-inch right-lateral fault offset in the Paso Robles-Wasco highway had some structural damage near its abutment. Bridges on the Parkfield-Cholame highway, which parallels and crosses the fault trace several times, had minor damage. For example, several steel swaybraces at one bridge located perhaps one hundred yards from the fault trace had buckled steel X-bracing. The fault trace went beneath a bridge near Parkfield; the bow in the bridge found after the earthquake may have been the result of pre- and/or post-earthquake fault creep as well as earthquake faulting, but the structural strength of the bridge had not been impaired.

Manuseripts received July 15, 1966

\footnotetext{
5 ESSA, Coast \& Geodetic Survey, San Francisco.

${ }^{6}$ Pacific Fire Rating Bureau, San Francisco.
} 